\title{
Brief Communication: Haplogroup X Confirmed in Prehistoric North America
}

\author{
Ripan S. Malhi ${ }^{1 *}$ and David Glenn Smith ${ }^{2,3}$ \\ ${ }^{1}$ Department of Human Genetics, University of Michigan, Ann Arbor, Michigan 48109 \\ ${ }^{2}$ Department of Anthropology, University of California, Davis, California 95616 \\ ${ }^{3}$ California Regional Primate Research Center, University of California, Davis, California 95616
}

KEY WORDS Native American; mtDNA; mitochondrial; ancient DNA; migration

\begin{abstract}
Haplogroup X represents approximately $3 \%$ of all modern Native North American mitochondrial lineages. Using RFLP and hypervariable segment I (HVSI) sequence analyses, we identified a prehistoric individual radiocarbon dated to $1,340 \pm 40$ years $B P$ that is a member of haplogroup X, found near the Columbia River
\end{abstract}

in Vantage, Washington. The presence of haplogroup $\mathrm{X}$ in prehistoric North America, along with recent findings of haplogroup X in southern Siberians, confirms the hypothesis that haplogroup $\mathrm{X}$ is a founding lineage. Am J Phys Anthropol 119:84-86, 2002. ๑ 2002 Wiley-Liss, Inc.
Using RFLP and hypervariable segment I (HVSI) sequence analyses, a mitochondrial DNA haplogroup that represents approximately $3 \%$ of all modern Native North American samples (Forster et al., 1996; Brown et al., 1998; Smith et al., 1999) and whose known worldwide distribution also includes West Asia and Europe (Torroni et al., 1996) has been identified. Due to the absence of haplogroup X in East Asia, presumed to be the homeland of the founders of Native America, diverse hypotheses were proposed to explain the presence of this haplogroup in North America. Brown et al. (1998) suggested the possibility of an ancient European migration to North America. Stanford (1997) suggested that early Holocene Europeans used a trans-Atlantic route to colonize the Americas and that Clovis technology was derived from the Solutrean tradition of the Iberian Peninsula. The presence of haplogroup $\mathrm{X}$ in North America might also be due to recent European admixture, since this haplogroup is found in high frequency in the Ojibwa (Brown et al., 1998; Malhi et al., 2001), among whom nuclear markers exhibit evidence of extensive European admixture (Szathmary and Auger, 1983).

Most of these hypotheses have been refuted by more recent research. Derenko et al. (2001) reported the presence of haplogroup X in Altaian populations from southern Siberia, where the other four Native American founding haplogroups are also present. Therefore, the Altai are the only known modern ethnic group whose membership represents all five Native American haplogroups and, assuming the New World was colonized by a single migration, constitute a possible origin of the founders of Native America. Despite unsuccessful attempts to extract ancient mtDNA from the Kennewick specimen
(Kaestle, 2000; Merriwether and Cabana, 2000; Smith et al., 2000b), other early Holocene skeletons in North America with cranial features unlike modern Native Americans (e.g., from Wizard's Beach and Hourglass Cave) exhibit haplogroups that are found in Native Americans but not in Europeans (Stone and Stoneking, 1996; Kaestle and Smith, 2001). These lines of evidence, together with recent criticism of similarities between the Clovis and Solutrean cultures (Straus, 2000) that were cited by Stanford (1997), strongly suggest that haplogroup X did not reach the Americas via an ancient European migration.

The wide geographic and linguistic distribution of haplogroup X in modern Native North American groups (Forster et al., 1996; Brown et al., 1998; Smith et al., 1999) and the predominance among those of a characteristic mutation in HVSI of the control region not found in European or Asian members of haplogroup $\mathrm{X}$ (the $\mathrm{G} \rightarrow \mathrm{A}$ transition at $\mathrm{np}$ $16,213)$, imply that it is a founding Native American lineage. In addition, the presence of three (allegedly full-blood) Algonquian-speaking Native Americans (Smith et al., 2000a; Malhi et al., 2001) who exhibit both the haplogroup $\mathrm{X}$ with the transition

\footnotetext{
Grant sponsor: NSF.
}

*Correspondence to: Ripan S. Malhi, Department of Human Genetics, 3726 Medical Science II, 1301 E. Catherine St., University of Michigan, Ann Arbor, MI 48109-0618. E-mail: malhi@umich.edu

\section{Received 3 August 2001; accepted 5 February 2002.}

DOI 10.1002/ajpa.10106

Published online in Wiley InterScience (www.interscience.wiley. com). 
at $\mathrm{np} 16,213$ and the rare Albumin marker, Albumin*Naskapi, also only found in North America, suggests that haplogroup $\mathrm{X}$ is not found in North America due to recent European admixture.

The most convincing evidence that haplogroup $\mathrm{X}$ is not the result of Viking or even more recent European admixture would be its presence in ancient Native Americans. Ancient samples from the Norris Farms site (Stone and Stoneking, 1998), the Win-

TABLE 1.

Nucleotide positions of the mutations for the prehistoric sample and lab researcher

\begin{tabular}{|c|c|c|c|c|c|c|c|c|c|}
\hline & $\begin{array}{l}\infty \\
\infty \\
0 \\
0 \\
-1\end{array}$ & $\begin{array}{l}\stackrel{m}{\sim} \\
\stackrel{0}{0}\end{array}$ & 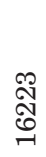 & 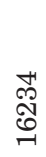 & $\begin{array}{l}\text { 연 } \\
\text { जै } \\
\text { ర్త-1 }\end{array}$ & $\begin{array}{l}\stackrel{N}{\sim} \\
\underset{\sim}{0}\end{array}$ & 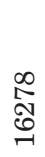 & 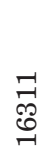 & 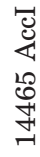 \\
\hline CRS & $\mathrm{T}$ & $\mathrm{G}$ & $\mathrm{C}$ & $\mathrm{C}$ & A & $\mathrm{C}$ & $\mathrm{C}$ & $\mathrm{T}$ & - \\
\hline $\begin{array}{l}\text { Vantage } \\
\text { RSM }\end{array}$ & $\mathrm{C}$ & A & $\mathrm{T}$ & $\dot{\mathrm{T}}$ & $\dot{\mathrm{C}}$ & $\dot{\mathrm{G}}$ & $\mathrm{T}$ & $\dot{\mathrm{C}}$ & + \\
\hline
\end{tabular}

CRS is the Cambridge Reference (Anderson et al., 1981). A dot (.) denotes identity with the Cambridge Reference sequence; a plus sign (+) denotes a site gain; minus sign (-) denotes a site loss.

a.

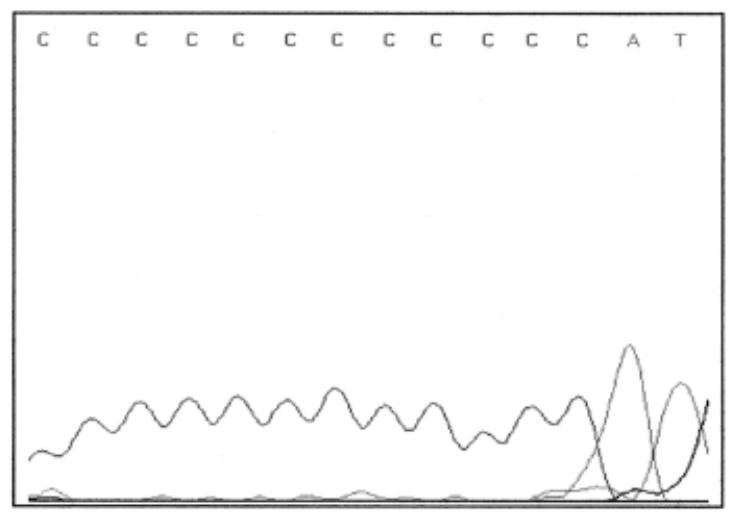

c.

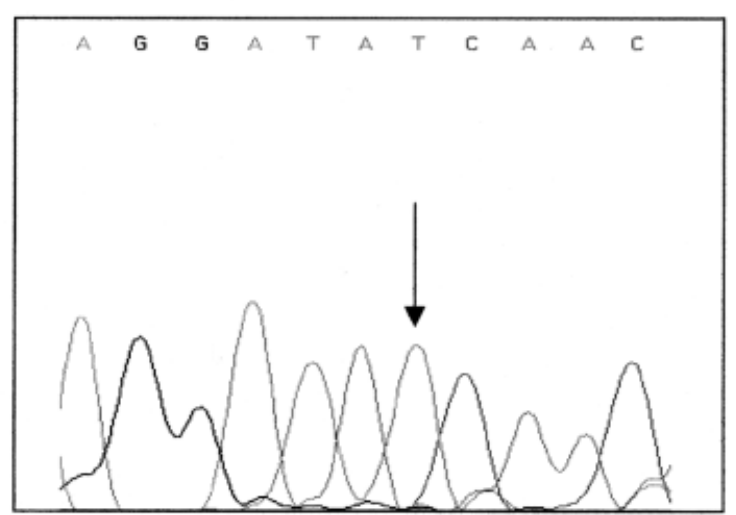

Fig. 1. Electropherogram of mutational sites for the prehistoric sample. a: Reverse complement electropherogram, displaying the Poly $\mathrm{C}$ region created by a $\mathrm{T} \rightarrow \mathrm{C}$ transition at $\mathrm{np} 16,189$. b: Reverse complement electropherogram, displaying the $\mathrm{G} \rightarrow \mathrm{A}$ transition and $\mathrm{C} \rightarrow \mathrm{T}$ transition at $\mathrm{np} 16,213$ and $\mathrm{np}$ 16,223, respectively. c: Electropherogram displaying the $\mathrm{C} \rightarrow \mathrm{T}$ transition at $\mathrm{np} 16,278$. dover site (Hauswirth et al., 1994), and the Amazon Basin (Ribeiro-Dos-Santos et al., 1996) exhibit the characteristic HVSI control region markers found in individuals assigned to haplogroup X, but they could not be confidently assigned that haplogroup because they were not tested for the AccI restriction site at $\mathrm{np} 14,465$. We confirmed the presence of haplogroup $\mathrm{X}$ in one prehistoric sample excavated at a site on the Columbia River near Vantage, Washington and radiocarbon dated to $1,340 \pm 40$ years $\mathrm{BP}$. Extensive precautions were taken to limit contamination of this sample and to detect any such contamination when it did occur. To eliminate surface contamination, the tooth was soaked in $10 \%$ bleach for $10 \mathrm{~min}$, followed by ultraviolet light $(254 \mathrm{~nm})$ irradiation. Extraction and amplification setups were performed in a dedicated ancient DNA laboratory that is routinely bleach-sterilized. Negative controls were included at various stages of the extraction and amplification setup processes. Multiple extractions were performed on the tooth to confirm haplogroup assignment. For a complete review of the extraction method and precautions used to prevent contamina-

b.

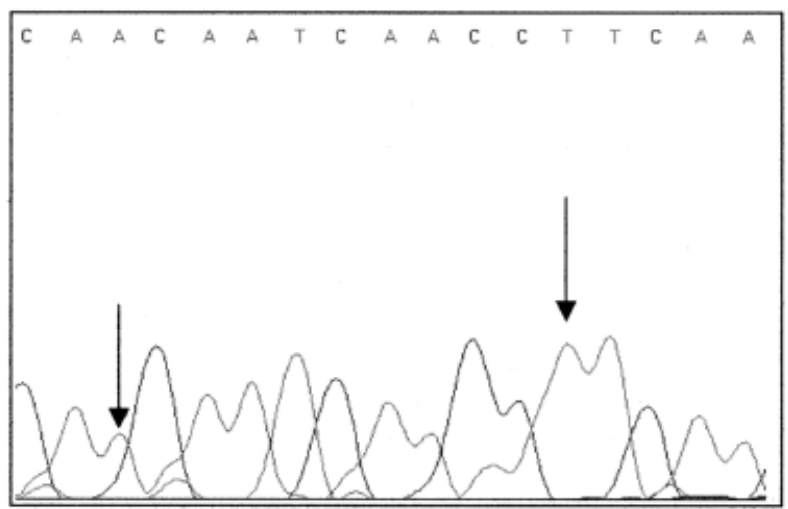


tion of the sample, see Smith et al. (2000b). Extraction and most amplification setup negative controls exhibited no evidence of contamination. When negative controls did exhibit contamination, the data was excluded from the analysis. Samples from the Vantage site (500-2,000 years BP) were well-preserved, and a high percentage (88\%) could confidently be assigned to a haplogroup (Malhi, 2001). This sample exhibited the HVSI control region markers (transitions at np 16,189, 16,223, and 16,278) and the AccI restriction site at $\mathrm{np} 14,465$ found in individuals assigned to haplogroup $X$ as well as the $\mathrm{G} \rightarrow \mathrm{A}$ transition at $\mathrm{np} 16,213$ that is specific to the Native American subclade of haplogroup X (Table 1; Fig. 1). To the best of our knowledge, this is the first evidence of haplogroup $\mathrm{X}$ in prehistoric America to be confirmed using both control region markers and the diagnostic restriction site gain in the coding region. This verifies a prehistoric presence of haplogroup $\mathrm{X}$ in North America that is probably derived from a Siberian source population.

\section{ACKNOWLEDGMENTS}

We thank Steven Hackenberger and James Chatters for providing information and the sample used in this study. This research was funded by an NSF Dissertation Improvement Grant to R.S.M.

\section{LITERATURE CITED}

Anderson S, Bankier AT, DeBruijn MHL, Coulson AR, Drouin J, Eperon IC, Neirlich DP, Roe BA, Sanger F, Schreier PH, Smith AJH, Staden R, Young IG. 1981. Sequence and organization of the human mitochondrial genome. Nature 290:457-465.

Brown MD, Hosseini SH, Torroni A, Bardlet H-J, Allen JC, Schurr TG, Scozzari R, Cruciana F, Wallace DC. 1998. mtDNA haplogroup X: an ancient link between Europe/Western Asia and North America? Am J Hum Genet 63:1852-1861.

Derenko MV, Grzybowski T, Malyarchuk BA, Czarny J, MiscickaSliwka D, Zakharov IA. 2001. The presence of mitochondrial haplogroup X in Altaians from south Siberia. Am J Hum Genet 69:237-241.

Forster P, Harding R, Torroni A, Bandelt H-J. 1996. Origin and evolution of Native American mtDNA variation: a reappraisal. Am J Hum Genet 59:935-945.
Hauswirth WW, Dickel CD, Rowold DJ, Hauswirth MA. 1994. Inter- and intrapopulation studies of ancient humans. Experientia 50:585-591.

Kaestle FA. 2000. Report on DNA analysis of the remains of "Kennewick Man" from Columbia Park, Washington. Washington, DC: National Park Service.

Kaestle FA, Smith DG. 2001. Ancient mitochondrial DNA evidence for prehistoric population movement: the Numic expansion. Am J Phys Anthropol 115:1-12.

Malhi RS. 2001. Investigating prehistoric population movements in North America with ancient and modern mtDNA. Ph.D. dissertation, Department of Anthropology, University of California at Davis.

Malhi RS, Schultz BA, Smith DG. 2001. Distribution of mitochondrial DNA lineages among Native American tribes of northeastern North America. Hum Biol 73:17-55.

Merriwether DA, Cabana GS. 2000. Kennewick Man ancient DNA analysis: final report, submitted to the Department of the Interior. Washington, DC: National Park Service.

Ribeiro-Dos-Santos AKC, Santos SEB, Machado AL, Guapindaia V, Zago MA. 1996. Heterogeneity of mitochondrial DNA haplotypes in pre-Columbian natives of the Amazon region. Am J Phys Anthropol 101:29-37.

Smith DG, Malhi RS, Eshleman J, Lorenz JG, Kaestle FA. 1999. Distribution of mtDNA haplogroup $\mathrm{X}$ among Native North Americans. Am J Phys Anthropol 110:271-284.

Smith DG, Lorenz J, Rolfs BK, Bettinger RL, Green B, Eshleman J, Schultz B, Malhi R. 2000a. Implications of the distribution of Albumin Naskapi and Albumin Mexico for New World prehistory. Am J Phys Anthropol 111:557-572.

Smith DG, Malhi R, Eshleman JA, Kaestle FA. 2000b. Report on DNA analysis of the remains of "Kennewick Man" from Columbia Park, Washington. Washington, DC: National Park Service.

Stanford D. 1997. Northern clans, northern traces: journeys in the ancient circumpolar world. Washington, DC: Smithsonian Institution.

Stone AC, Stoneking M. 1996. Genetic analyses of an 8000 yearold Native American skeleton. An Biomol 1:83-87.

Stone AC, Stoneking M. 1998. mtDNA analysis of a prehistoric Oneota population: implications for the peopling of the New World. Am J Hum Genet 62:1153-1170.

Straus LG. 2000. Solutrean settlement of North America? A review of reality. Am Antiq 65:219-226.

Szathmary EJE, Auger F. 1983. Biological distances in and genetic relationships within Algonkians. In: Steegmann AT Jr, editor. Boreal forest adaptations. New York: Plenum Press. $\mathrm{p}$ 289-315.

Torroni A, Huoponen K, Francalacci P, Petrozzi M, Morelli L, Scozzari R, Obinu D, Savontaus ML, Wallace DC. 1996. Classification of European mtDNAs from an analysis of three European populations. Genetics 144:1835-1850. 